\title{
ROLE OF NUCLEAR FACTOR (NF)-kB PROTEIN IN ATHEROSCLEROSIS AND DIABETES: A POTENTIAL THERAPEUTIC TARGET*
}

\author{
A. Dolzhenko ${ }^{1}$, T. Richter ${ }^{2}$, S. Sagalovsky ${ }^{2}$ \\ ${ }^{1}$ Biomedical Research Unit, Institute Molecular Medicine Martin-Luther University Halle-Wittenberg, Germany; \\ ${ }^{2}$ Department of Cardiology Clinic Median, Bad Lausick, Germany \\ s.sagalovsky@gmail.com
}

Cardiovascular diseases and diabetes are the leading cause of death in developed countries and progressively increasing their impact on mortality in developing countries despite changes in lifestyle and the use of preventative pharmacological approaches. Atherosclerosis is the common pathological substrate underlying cardiovascular diseases. One of the first steps in atherogenesis is activation of vascular endothelium, which leads to recruitment of blood-borne leukocytes, such as monocytes and $\mathrm{T}$ lymphocytes. Once monocytes are recruited to the artery wall, these differentiate into macrophages and/or lipid-laden foam cells after lipid engulfment. This macrophage and T-cell infiltrate is a typical feature of the socalled 'fatty streaks,' proposed to represent an early stage of atherogenesis. This is followed by smooth muscle cell migration from the media to the intima, with subsequent proliferation and deposition of extracellular matrix, and organization of lesions into 'mature' plaques. At this stage, in humans plaques are typically characterized by a fibrous cap covering a raised lesion inside the internal elastic lamina composed of fibrous tissue, with or without a core filled with macrophage- and smooth muscle cell-derived foam cells and extracellular lipid deposits, causing a variable degree of stenosis. Many pathological substrates have been described to underlie this event (plaque rupture, erosion, calcified nodule), and a complex array of mechanisms - platelet activation, tissue factor (TF) expression leading to activation of coagulation, matrix metalloproteinase (MMP) expression and activation leading to fibrous cap thinning and rupture, pro-inflammatory mediators - have been implicated [1]. In the past decade, a deeper understanding of the contribution of inflammation and immune responses to the pathogenesis of atherosclerosis has redefined atherosclerosis as an inflammatory disease [2]. Indeed, it is now apparent that atherosclerosis and chronic inflammatory diseases such as diabetes display many common features, including extravasation of leukocytes and production of cytokines, chemokines and MMP. Studies performed is a variety of cell and animal based experimental systems that NF-kB activation is a key event early in the pathobiology of diabetes. With relevance to this review, atherosclerosis and inflammatory diseases, such as diabetes, involve activation of nuclear factor $\mathrm{kB}(\mathrm{NF}-\mathrm{kB})$, which is now

\footnotetext{
${ }^{*}$ This work was supported in part by grant (P23690) from Martin-Luther University.

All authors read and approved the final manuscript.

The authors declare no conflict of interest.

Manuscript received 04.11.2015.
}

Проблеми ендокринної патологї № 4, 2015 
considered to be a major, if not the major, transcription factor regulating many functions. Moreover, NF-kB activation is thought to lie downstream of many of the stimuli proposed to be involved in atherosclerosis, such as modified lipoproteins (LDL), cytokines and infectious agents. Better understanding of the regulation of NF-kB will provide a platform for development of specific therapeutic agents target towards the inflammatory diseases.

The NF-kB signaling pathway and its regulation. NF-kB comprises a family of transcription factors first described as Blymphocyte-specific nuclear proteins, essential for transcription of immunoglobulin kappa (k) light chains. Mammalian cells contain five NF-kB subunits — relA (p65), relB, c-rel, p50 and p52 - which form homo- and heterodimers and are characterized by the conserved N-terminal 'rel homology' domain
(Fig. 1). NF-kB is sequestered in the cytoplasm with members of the inhibitor of NFB ( $\mathrm{IkB})$ family, which consists of IkBa, IkBh, $\mathrm{IkBq}$ and $\mathrm{Bcl}-3$ [3]. In the canonical activation pathway, liberation of NF-kB from the inactive complex is initiated by phosphorylation of IkB on N-terminal serines. Phosphorylated IkBs are recognized by an E3 ubiquitin kinase complex and degraded by the $26 \mathrm{~S}$ proteasome. Amino acid residues Ser-32 and Ser-36 of IkBa were identified as essential for phosphorylation whereas Lys-21 and Lys-22 for the ubiquitination process. IkB degradation leads to the exposure of a nuclear translocation sequence of the NF-kB dimer, allowing it's nuclear translocation and DNA binding [4]. Central to the NF-kB cascade is the multi-subunit kinase IkB kinase (IKK) complex [5], which includes IKK-a (IKK-1) and -h (IKK-2) as well as regulatory subunits such as

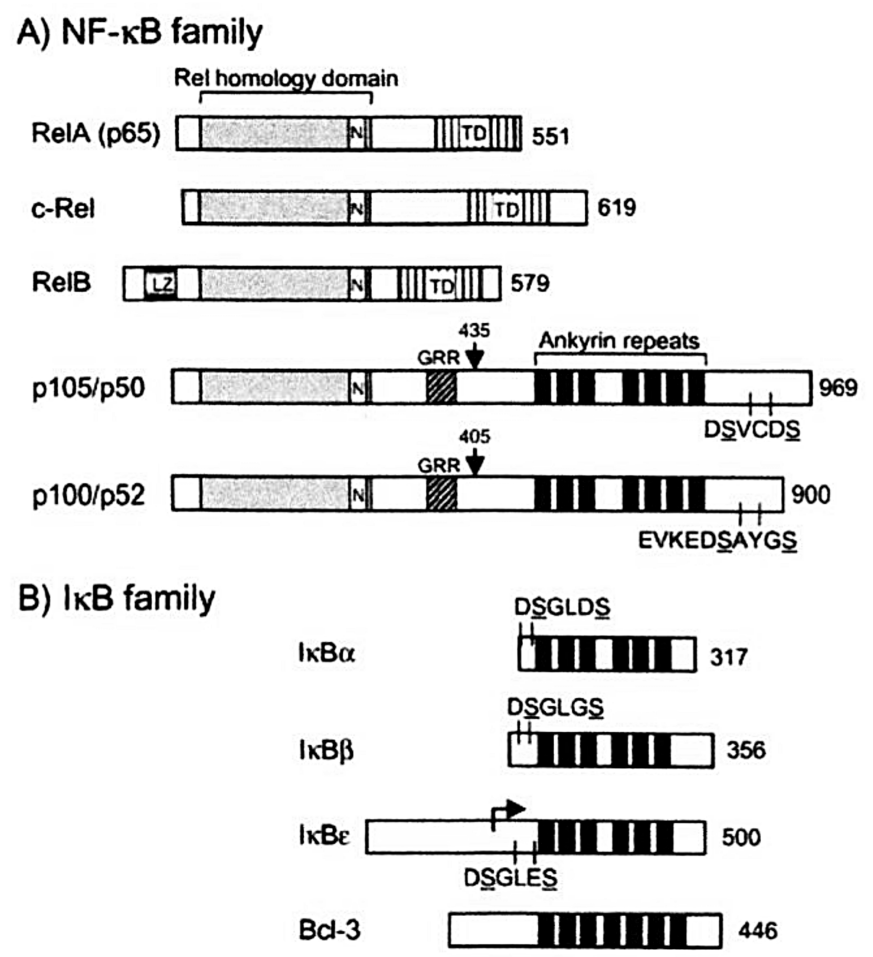

Fig. 1. Mammalian NF-kB and IkB family members. NF-kB family members possess a structurally conserved Rel-homology domain (RHD), which contains a nuclear localization domain $(\mathrm{N})$, a dimerization motif, and a DNA-binding domain. RelA, c-Rel, and RelB also have a non-homologous transactivation domain (TD). RelB also contains a leucine-zipper motif (LZ). The IkB family members, including p105 and $\mathrm{p} 100$, are characterized by ankyrin repeats. The amino-acid sequences of the phosphorylation sites triggering their degradation/processing are designated. The glycine-rich region (GRR), which is required for the processing of p105 and p100, is also indicated. 
NEMO/IKK-g and IKAP. IKK-2 was shown to have a higher kinase activity for IkBa and to be the predominant kinase responsible for the phosphorylation of $\mathrm{IkBa}$ in response to tumor necrosis factor a (TNFa), interleukin (IL)-1, lipopolysaccharide (LPS) and doublestranded RNA (Fig. 2) [6-10]. IKK-2 knockout mice die as embryos and show massive liver degeneration due to hepatocyte apoptosis, a phenomenon similar to that of mice deficient in relA or IkBa. NF-kB activation by IL-1 or TNFa is strongly impaired although not completely abolished. On the other hand, IKK-1 knockout mice have many morphogenetic abnormalities, including shorter limbs and skull, a fused tail, and die perinatally. They have hyperproliferative epidermal cells that do not differentiate, but IL-1- and TNFainduced NF-kB activation in embryonic fibroblasts is normal, as is $\mathrm{IkB}$ phosphorylation and degradation. This suggests that IKK-2 is crucial for NF-kB activation upon inflammatory stimuli, but also that IKK-1 or presently unknown kinases may contribute to this action.

Activation of the IKK complex is thought to be mediated by phosphorylation of IKK-1 or IKK-2 by upstream kinases, including members of the mitogen-activated protein kinase kinase kinase family or NF-kB inducing kinase (NIK) [11]. NIK, in particular, has reported to play a major role in NF-kB activation [3]. However, recent studies in NIK-deficient mice and human primary cells have questioned its physiological role in NF-kB activation and have suggested that its function may be restricted to signaling through the lymphotoxin B receptor [12]. Although many stimuli have the potential to activate the NF-kB pathway, the responses elicited are both cell and stimulus specific, suggesting that not all activators utilize the same signaling components and cascades. There are several levels of control and diversification. For instance, the spectrum of adaptor proteins and kinases differs between different stimuli and receptors - for example, adaptors activated via Toll-like receptors (TLR) and IL-1 receptors are distinct from those recruited by $\mathrm{TNF}$ receptors. IkB kinases are also an important level of control, in that IKK-1 regulates mostly morphogenetic events, whereas IKK-2 is involved in inflammatory signaling. Moreover, there is heterogeneity of require-

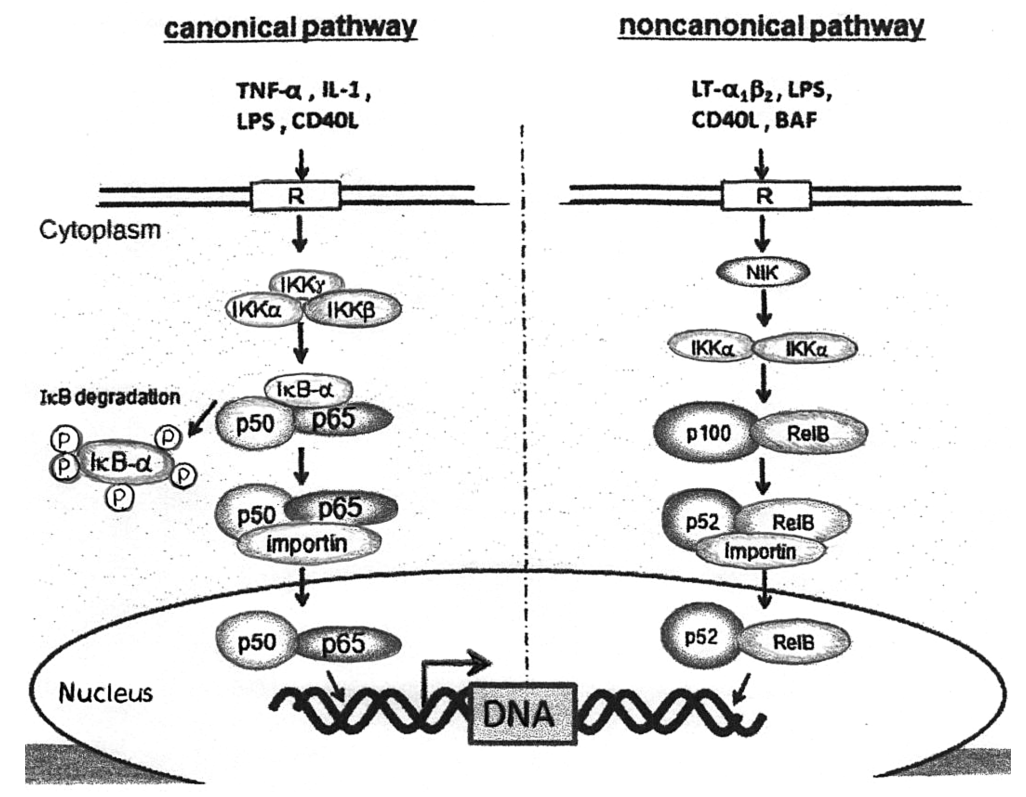

Fig. 2. Classical and alternative NF-kB activation pathways. In classical NF-kB activation, signaling is typically triggered through TNFR, IL-1R, or TLR. Signals mediated by MAP/ERK kinase kinase 3 (MEKK3) and IKKb finally result in the degradation of IkBa and the translocation of the RelA/p50 homodimer to the nucleus. In the alternative NF-kB activation pathway, signals triggered via CD40, LTbR, or BAFF-R are mediated by NIK and IKKa, which leads to p100 processing and the translocation of p52 dimers into the nucleus. 
ment of IKK-2 in different cell types and in response to stimuli [13]. Novel IkB kinase complexes have been recently identified, including IKK-I (IKK-q) which shares $30 \%$ overall identity with IKK-1 or IKK-2. Differential binding by NF-kB dimers is another important level of control in this versatile pathway. NF-kB consensus binding sites are decameric sequences of NF-kB (5V-GGGRNNYYCC-3V, where R indicates $\mathrm{A}$ or $\mathrm{G}, \mathrm{Y}$ indicates $\mathrm{C}$ or $\mathrm{T}$ and $\mathrm{N}$ indicates any nucleotide), or kBlike motifs (5V-HGGARNYYCC-3Vwhere $\mathrm{H}$ indicates A, $\mathrm{C}$ or $\mathrm{T}, \mathrm{R}$ indicates $\mathrm{A}$ or $\mathrm{G}, \mathrm{Y}$ indicates $\mathrm{C}$ or $\mathrm{T}$ and $\mathrm{N}$ indicates any nucleotide). Different NF-kB dimers exhibit different binding affinities for NF-kB or kB-like sites (reviewed in Refs) [14-16]. For example, the NF-kB sequence contained in some MMP genes allows predominantly binding of $\mathrm{p} 50 / \mathrm{p} 65$, while other $\mathrm{NF}-\mathrm{kB}$ dimers (c-Rel/p50) are involved in regulation of other mediators (such as TF, whose promoter contains a kB-like site). In addition, while all five NF-kB subunits contain the 'rel homology' domain, only relA and c-Rel contain a transactivation domain.

Indeed, there is growing evidence that the p50/p50 homodimer, lacking transactivating potential, may inhibit gene transcription. The major domain sensitive to phosphorylation is the transactivation domain located in the NF-kB C-terminal region [7]. Both stimulatory and inhibitory phosphorylations of relA have been reported. Phosphorylation of Ser-927 within the p105 C-terminal PEST region by IKK has been reported to contribute to NF-kB activation [6]. Several upstream kinases have been implicated in the transactivating event, including phosphatidyl inositol 3-kinase, p38 mitogen-activated protein kinase (MAPK) and p42/44gen-activated protein kinase (MAPK) and p42/44 MAPK [17]. Hence, it is the differential expression of NF-kB components in tissues, cell types and possibly diseases, together with differential interactions with the transcription apparatus that contributes to coordinated regulation by NF-kB of complex cellular responses. Another mode of specificity in NF-kB-dependent gene activation lies in its ability to orchestrate gene expression in concert with other transcription factors. For instance, the organization of the cytokine-in- ducible element in the Eselectin promoter is remarkably similar to that of the interferon$\mathrm{h}$ gene, in that both require NF-kB, ATF-2 and HMGI(Y) [18], whereas another adhesion molecule, vascular cell adhesion molecule-1 (VCAM-1), is induced through interactions of NF-kB with IRF-1 and HMG-I(Y) and also depends on constitutively present SP-1. The ability of NF-kB to interact with AP-1 is of particular importance, as many of the inflammatory genes require these two transcription factors working cooperatively, including VCAM-1, IL-8, cyclooxygenase (COX)-2, monocyte chemoattractant protein-1 (MCP-1) and MMP-13 [19-20]. A peculiarity of NF-kB is the rapid nature of its activation and downregulation. NF-kB activation induces IkBa, allowing switching off of the system. Hence, in physiological conditions, NF-kB activation is a transient phenomenon, which allows appropriate expression of immune and 'stress' genes. In contrast, prolonged or inappropriate activation of the NF-kB pathway is a feature of diseases such as RA, asthma and inflammatory bowel disease, where its disregulation may cause the enhanced inflammatory response associated with these conditions. NF-kB is now also thought to play an important role in the pathogenesis of atherosclerosis and acute coronary syndromes.

NF-kB activation in atherosclerosis. Activated NF-kB has been identified in situ in human atherosclerotic plaques. De Winther et al. detected nuclear translocation of NF-kB subunit relA in the intima and media of atherosclerotic lesions, in smooth muscle cells, macrophages,endothelial cells and, to a lesser extent, T cells [21]. In situ analysis of p50 and relA in normal vessel walls revealed diffuse cytoplasmic expression, but no nuclear accumulation, suggesting that the system is quiescent. NF-kB activation seems to be more prominent in acute complications of atherosclerosis, such as acute coronary syndromes.

Nuclear NF-kB binding activity has been found in peripheral blood mononuclear cells and myocardial biopsies of patients with unstable angina. Nuclear translocation of relA is higher in unstable coronary atherectomies, but also present instable angina patients [22]. Despite these reports in human atherosclero- 
sis, the majority of our knowledge has been gathered from studies using animal models of atherosclerosis. Activated NF-kB was detected in coronary arteries of pigs fed a hypercholesterolemic diet and in arterial smooth muscle cells after balloon injury in a rat model [23]. In LDL receptor (LDL-R) knockout mice, expression of relA, $\mathrm{IkBa}$ and $\mathrm{IkBh}$ was 5 - to 18-fold higher in a region of ascending aorta and arch highly predisposed to atherosclerotic lesion formation.

However, nuclear translocation of relA was only found after initiation of an atherogenic diet or, more prominently, after systemic injection of LPS, and even then, only in regions predisposed to atherosclerosis $[21,24]$. As discussed previously, IKK-2 is the main component of the IKK complex. Bone marrow transplantation of LDLR-deficient mice with macrophages lacking IKK-2 increased atherosclerotic lesion size, with more infiltrates in early lesions and more necrosis in advanced stages of disease [25]. The same group also studied mice targeted in NF-kB p50, which lacks the transactivation domain and can heterodimerize with p65 to form the most common NF-kB dimer, but can also form homodimers, which can inhibit signaling $[20,26]$. Studies using bone marrow transfers from p50deficient mice to LDL-R-deficient mice showed a reduction in lesion size, but a surprising shift towards a different plaque phenotype, characterized by reduced foam cell numbers and an increase in macrophages and $\mathrm{T}$ cells, and the appearance of B cells (traditionally not present at the lesion site) [27]. These very recent targeted gene deletion studies have highlighted that the involvement of NF-kB in atherogenesis is far more complex than expected. More research is therefore needed to identify the key stimuli leading to NF-kB activation and the signaling involved, in order to identifying suitable therapeutic targets, less likely to interfere with the entirety of the pathway.

Stimulators for NF-kB activation in atherosclerosis. In the context of atherosclerosis, there are many stimuli with the potential to activate NF-kB, including local factors such as vascular injury, as well as modified LDL, infectious agents and cytokines, reflecting the multifactorial pathogenesis of atherosclerosis.
It is difficult to determine which of these stimuli are responsible for activation of NF-kB in vivo, and indeed, NF-kB may in fact be a convergence point, integrating these different stimuli throughout the lifetime of an individual (Fig. 2).

Local factors. The prototypical stimulus initiating atherogenesis ivascular injury $[2,28]$. Once endothelium is denuded, platelet adhesion and activation are thought to occur, leading to vascular smooth muscle cell migration and proliferation. These events may involve NF-kB activation. Using a balloon catheter injury model in the rat carotid artery, low levels of constitutively activated p50, relA and c-Rel were shown in normal carotid arteries, but immediately after injury, levels of IkBa and IkBh were dramatically reduced and macrophage infiltration, expression of VCAM-1 and MCP-1 occurred. More recently, IkBa adenovirus was applied in a rabbit iliac artery restenosis model and shown to reduce intercellular adhesion molecule-1 (ICAM-1) and MCP-1, as well as reducing recruitment of macrophages and lumen narrowing [29]. Similar results were obtained using NF-kB decoy oligodeoxynucleotides [30]. It is now recognized that hypoxia may also contribute to development of cardiovascular disease. The adventitia and outer media of large- and medium-sized arteries are vascularized by vasa vasorum, which provide oxygen and nutrients to the external twothirds of the vessel wall. In atherosclerosis, the augmented arterial wall thickness may lead to hypoxia, and indeed, there have been reports of adventitial neovascularisation of vasa vasorum in experimental models of atherosclerosis, which could result from hypoxia-induced angiogenesis.

A key regulator of oxygen homeostasis is hypoxia inducible factor (HIF)-1, levels of which are regulated through a mechanism involving oxygen-dependent proteolysis of HIF$\alpha$. In hypoxic cells, HIF-a degradation is suppressed, allowing HIF-a to accumulate within the nucleus, resulting in transcriptional activation of cytokines such as vascular endothelial growth factor (VEGF). However, hypoxia is also thought to activate NF-kB, albeit through an atypical pathway, involving degradationindependent phosphorylation of Tyr-42 in the 
N-terminal domain of IkBa, which may prevent interactions with the IKK complex and inhibit phosphorylation of Ser-32 and Ser-36.

Modified low-density lipoproteins. Lipids represent a key component of the atherosclerotic plaque. LDL retained in the intima undergo oxidative modifications resulting in the production of oxidized LDL. Minimally oxidized LDL stimulate endothelial cells to produce NF-kB-dependent chemokines and adhesion molecules [31]. In a study of LDL oxidation in vivo when human LDL particles were injected, these localized in the arterial wall and underwent oxidative modification accompanied by activation of endothelial NFnB and expression of NF-kBdependent genes. However, in vitro evidence has shown that the regulation of NF-B by LDL is complex and often dependent on incubation times and concentrations used. For example, short-term exposure of monocytes to oxidized LDL activates NF-kB, but longer exposure may suppress NF-kB-dependent responses. Pretreatment with oxidized LDL results consistently in many in vitro systems in inhibition of LPS-induced NF-kB activation [21,32]. Moreover, modified LDL contain multiple constituents whose identity and effects on signaling have been only partially unraveled. Some components of oxidized LDL such as lysophosphatidylcholine can activate NF-kB in endothelial cells [33].

In contrast, an inhibitory effect on NF-kB has been proposed for 4 -hydroxynonenal, one of the most abundant aldehydes formed during oxidation of LDL, which has been reported to inhibit NF-kB-dependent transcriptional activation of inducible nitric oxide (NO) synthase (iNOS) in smooth muscle cells [34]. Similarly, oxidized PAPC (oxidized 1-palmitoyl-2-arachidonoyl-snglycero- 3-phosphocholine, a component of minimally oxidized LDL) has been described as inhibiting NF-kB binding to DNA.

Metabolic factors. Although the mechanisms are uncertain, it is thought that homocysteine creates oxidative stress by altering the redox thiol status of the cell. A consequence of these effects is the activation of NF-kB. In smooth muscle cells, homocysteine leads to both an increase in NO production and an NF-kB-mediated increase in the expression of iNOS [35]. Advanced glycation end products (AGE), formed through non-enzymatic reactions of reducing sugars with the amino groups of proteins, nucleotides and lipids, have recently attracted an interest as candidate stimuli. Accumulation of AGE has been found in atherosclerotic plaques [36], and expression of RAGE (receptor for AGE) in endarterectomy specimens has been described. AGE are thought to activate endothelial cells and monocytes through NF-kB.

Microbial agents. A pathogenic role for infectious agents in atherosclerosis has been suggested. For example, Chlamydia pneumonia express molecules such as LPS and heat shock proteins (HSP), which potently activate the innate immune response. Initial recognition of microbial antigens is mediated by TLR, and currently, at least nine different TLR have been identified in mammals, each one with a certain degree of specificity. For example, TLR-4 is essential for signaling via LPS from Gram-negative bacteria, exceptions being Leptospira interogans and Porphyromonas gingivalis, recognized by TLR-2. LPS is thought to activate endothelial cells through TLR-4, and possibly TLR-2, to release IL- 6 and IL-8 via an NF-kB-dependent mechanism involving IKK-2 $[13,27]$. This is likely to involve an adaptor molecule, MyD88, the N-terminal region of which contains a death domain (DD), which recruits of IL-1 receptor-associated kinase (IRAK)-1 and -2. These kinases, in turn, recruit TNF receptor-associated factor (TRAF)-6, and signaling progresses through IKK to NF-kB activation [38].

Cytokines. The concept that the atherosclerotic environment exhibits inflammatory and immune features is supported by the presence in plaques of pro-inflammatory cytokines, including TNFa [39] and IL-1 [40], both of which activate NF-kB. Two types of TNF receptor have been described, p55 and p75 (TNF receptor 1 or CD120a and TNF receptor 2 or CD120b). The p55 TNF receptor has an intracellular $\mathrm{DD}$ and is required for $\mathrm{TNFa}$-induced apoptosis. $\mathrm{TNFa}$ signaling through p55 can also induce NF-kB activation. These signals have been shown to bifurcate at the level of TNF receptorassociated death domain protein (TRADD), 
where TRADD interacts with FADD to transduce the apoptotic signal and with TRAF2 to induce NF-kB activation. The p75 TNF receptor does not possess a DD but seems to form a heterodimeric complex with TRAF-1 and TRAF-2. There are two forms of the IL-1 receptor, which are members of the IL-1 receptor/TLR superfamily. The homology of the intracellular portion of TLR to the intracellular portion of IL-1 type I receptor suggested that these receptors might use an analogous framework for signaling, and indeed, the trimeric complex recruits MyD88 and then IRAK-1 and -2 . These kinases, in turn, recruit TRAF-6 and activate NF-kB [41]. The potent vasoconstrictor angiotensin II may play a role in atherosclerosis due to its effects on blood pressure and smooth muscle cell growth and has been proposed to act in the plaque as an 'honorary' cytokine. In fact, angiotensin II induces expression of adhesion molecules (VCAM-1, ICAM-1 and Eselectin) and IL-6 in smooth muscle cells at least in part through NF-kB [42].

T-lymphocyte-dependent signaling. Analysis of $\mathrm{T}$ cells in atherosclerotic plaques reveals a memory $\mathrm{CD} 45 \mathrm{RO}+$ phenotype, expression of activation markers such as HLADR, VLA-1, CD69, CD40 ligand and CD25 and consistent enrichment of T-helper 1 cells.

Both T-cell receptor (TCR)-dependent and -independent pathways are thought to be involved in the activation of lymphocytes in the atherosclerotic plaque [43]. Antigenspecific T-cell activation depends on TCR interaction with peptides presented by MHC, as well as interactions of costimulatory molecules with their ligands. NF-kB is likely to play an important role both in T-cell activation and in T-cell dependent signaling to neighboring cells. Most co-stimulatory molecules activate NF-kB, and the first two inducible T-cell genes shown to be regulated by NF-kB were those for IL- 2 and a chain of the IL-2 receptor. Moreover, NF-kB regulates T-cell signaling to effector cells. Cell contactmediated activation of endothelial cells and macrophages by $\mathrm{T}$ cells leads to expression of cytokines, MMP and TF. Different pathways of T-cell activation result in differential responses of the target cells.

Our own studies revealed that TCR-acti- vated lymphocytes induce monocyte production of $\mathrm{TNF} \alpha$ and the chiefly anti-inflammatory cytokine IL-10. In contrast, cytokine-activated lymphocytes selectively induced high levels of TNFa, but no detectable IL-10, in an NF-kB-dependent manner. In atherosclerosis, conditions for generating cytokine-activated $\mathrm{T}$ cells (production of TNFa, IL-6, IL-2) are likely to be present, suggesting that $\mathrm{T}$ cells may stimulate monocyte/macrophages to release TNFa through activation of NF-kB. Molecules involved in contact mediated activation by $\mathrm{T}$ cells are likely to include membrane TNFa and CD40 ligand. In human primary cells, IKK-2 is essential for CD40 ligand-induced NF-kB activation $[6,21]$. In atherosclerosis, T-cell-mediated contact-dependent activation via CD40 might be an important mechanism of perpetuating inflammation in vivo, via activation of NF-kB in effector cells [44].

NF-kB regulates the main features of atherosclerotic plaques. As discussed earlier, many stimuli relevant to the pathogenesis of atherosclerosis have the potential to activate the NF-kB signaling pathway, inducing many downstream events (Fig. 2). In essence, all of the cells which can contribute to plaque initiation and progression - endothelial and smooth muscle cells, macrophages and immune cells - are likely to activate the NF-kB pathway.

Activation of endothelium and recruitment of mononuclear cells: early stages of atherogenesis. Vascular endothelial activation is a prominent feature of atherosclerosis and is traditionally regarded as the initial step leading to atherosclerosis. Endothelial cells express transcripts encoding p50/p105, p65 and c-rel, steady-state levels of which are increased by TNFa. It was noted early on that most genes expressed in endothelial cells in response to LPS, IL-1 and TNFa contained NFnB binding sites in their promoter regions [45]. Sequence analysis of the $5 \mathrm{~V}$ flanking region of the E-selectin gene revealed at least three consensus DNA-binding sequences for NF-kB. Other examples of NFnB regulated genes include VCAM-1, E selectin, IL-1, IL-6, TF, plasminogen activator inhibitor-1, COX-2 and iNOS. For example, adenovirus mediated overexpression of $\mathrm{IkBa}$ 
and a dominant negative form of IKK-2 inhibited TNFa-induced expression of Eselectin, VCAM-1 and ICAM-1 [46]. Induction of IL-6, MCP-1 and Groa, as well as TF, was also suppressed. This was associated with reduced arrest, spreading and transmigration of monocytes. Some of these inflammatory mediators, such as IL-1, can also per se activate NF-kB, hence creating a positive autoregulatory loop that maintains the activation of NF-kB and amplifies the inflammatory response.

The initiation of the immune response in atherosclerosis: potential role of $\mathbf{T}$ cells. In atherosclerosis, candidate antigens for the immune response are thought to include oxidized LDL and HSP. T cell clones obtained from the human atherosclerotic plaques recognize oxidized LDL as a classical, HLA DR-dependent antigen. ApoE knockout mice exhibit a modified form of LDL in aortic lesions and elevated serum levels of antibodies against modified LDL. Crucial to the presentation of antigens and the activation of antigen-specific $\mathrm{T}$ cells are dendritic cells (DC) that constantly circulate from the tissues to the secondary lymphoid organs, where they activate $\mathrm{T}$ cells and initiate adaptive immunity to the antigens recognized. DC has been found in human atherosclerotic lesions [47]. One of the major signals involved in the regulation of this process is likely to be CD40 ligand interactions between $\mathrm{DC}$ and $\mathrm{T}$ cells. CD40 ligand expressed by T cells activates DC and enhances DC T-cell stimulatory ability, by inducing cytokine production and upregulating antigen-presenting and co-stimulatory molecules in a process that requires IKK-2 but not NIK. In contrast, activation of DC by LPS does not require either IKK-2 or NIK [48].

Monocyte/macrophages in atherosclerosis: key players in the inflammatory process. Macrophages resident in atherosclerotic lesions are derived from blood-borne monocytes and express cytokines, chemokines and growth factors, such as TNFa, IL-6, IL-8 and MCP-1 [49]. The requirement for NF-kB is complex and varies according to the stimulus and the species studied. For example, showed that overexpression of IkBa in human macrophages inhibited LPS-induced production of TNFa, IL-1, IL-6 and IL-8, but not of anti-inflammatory cytokines IL-10 and IL-11. Interestingly, not all stimuli use NF-kB to upregulate pro-inflammatory cytokines, in that responses to the yeast cell product zymosan were unaffected. More recently, we showed that dominant negative IKK-2 adenovirus did not inhibit LPS-induced cytokine (TNFa, IL-6 and IL-8) production [13], although VEGF expression was reduced. Release of cytokines and VEGF from CD40 ligandactivated macrophages did, however, require IKK-2 [9, 50].

In contrast to human monocyte/macrophages, in vitro studies showed that $\mathrm{p} 50$-deficient bone marrow-derived macrophages show reduced LPS-induced endocytosis of modified lipoproteins and prolonged TNFa secretion, as well as an increase in IL-10 and IFNg, but a reduction in MCP-1, IL-6 and IL-12. The deletion of $\mathrm{p} 50$, which has been proposed to have an antiinflammatory role, is associated with smaller atherosclerotic lesions, but a more inflammatory phenotype. In addition, in contrast to human cells, deletion of IKK-2 in murine macrophages was associated with reduced TNFa, IL-6 and IL-10 production, in the absence of any modification of LPS-induced modified LDL uptake [25]. IKK-2 deletion in this mouse model increased atherosclerotic lesions, with more prominent necrosis. It is possible to speculate that NF-kB may be involved in vivo in the resolution of inflammation. In a model of acute lung inflammation, NF-kB activation in leukocytes during the onset of inflammation was associated with pro-inflammatory gene expression, whereas such activation during the resolution of inflammation was associated with the expression of anti-inflammatory genes and induction of apoptosis, that per se has a less pro-inflammatory impact than necrosis. The consequences of NF-kB blockade seem at this stage far more complex than can be foreseen, due to the central role of NF-kB in several key cellular functions. Further studies in human cells are needed to assess the best therapeutic targets within the pathway. Critically, different features of atherosclerotic lesions between humans and animal models, together with differences in regulation of pro-inflammatory and anti-inflammatory cytokines upon NF-kB blockade between human and animal models, 
point towards the need for more evidence to be gathered in the setting of human disease.

Smooth muscle cell responses in atherosclerosis and restenosis: life and death in the atherosclerotic plaque. Smooth muscle cell migration from the media to the intima and proliferation is a trademark of atherosclerotic plaques. Furthermore, neointimal hyperplasia characterized by smooth muscle cell proliferation is the main feature of restenosis after percutaneous interventions. As discussed earlier, vascular injury is a major stimulus for NF-kB activation and smooth muscle cell proliferation. NF-kB is central to smooth muscle cell proliferation and survival [51] via induction of genes with survival and protective functions. Cell survival is regulated by the balance of caspases and members of the inhibitors of apoptosis (IAP) and Bcl2 families. When caspases are activated, these cleave a variety of proteins, including certain key substrates in the cell, and it is the changes in function of the latter that kill the cell via apoptosis. The functions of the caspases are modulated by the IAPs, including NAIP, cIAP-1 and -2, XIAP and survivin. Death receptors, such as Fas/CD95 or TNF receptor 1, can trigger caspase activation. The DD of TNF receptor 1 interacts with TRADD and thereby with FADD that, in turn, binds pro-caspase-8 and -10 . By being brought into proximity with one another, these pro-caspases cleave their nearest neighbors to form active, mature caspases which now efficiently cleave pro-caspase3 (and other executioner caspases) to allow apoptosis to proceed. Additionally, however, TRAF-1/TRAF-2 heterocomplexes can interact with c-IAP-1 and -2 . Signaling in response to TNFa can therefore trigger either the extrinsic apoptotic pathway via FADD and caspases, or cell survival through TRAFs/IAPs. There is a close interaction between the IAP and NF-kB pathways. As discussed previously, TRAFs are upstream of NF-kB activation. Activation by $\mathrm{TNFa}$ of a fibrosarcoma line expressing a form of IkBa that cannot be phosphorylated by IKK inhibits caspase- 8 activation.

Several studies have also demonstrated that overexpression of IkBa in endothelial cells results in $\mathrm{TNF} \alpha$-induced cell death through suppression of IAPs. In smooth muscle cells induction of c-IAP-2 has also been found to be NF-kB dependent. Finally, smooth muscle cells are key players in the production and degradation of extracellular matrix within the plaque.

Role of NF-kB in the pathogenesis of type 1 diabetes. In type 1 diabetes mellitus, pancreatic $\beta$-cells are the target of an autoimmune attack that is mediated in part by cytokines, such as interleukin-1 and interferon. There is no detectable NF-kB activity in resting $\beta$-cells, however upon exposure to IL-1, NF-kB is activated and translocated to the nucleus [6]. These cytokines modify the expression of hundreds of genes leading to $\beta$-cell dysfunction and death by apoptosis. Several of these cytokine-induced genes are regulated by the activation of NF-kB. One study has revealed that more than 66 genes are modified in the $\beta$-cell upon exposure to these cytokines [6]. Importantly, several of these genes are putative targets for NF-kB. Among these are genes that encode for iNOS, pro-apoptotic cell surface Fas, the chemokine MCP-1, and MnSOD, which may participate in $\beta$-cell defense [6]. The activation of NF-kB can trigger pro- or anti-apoptotic cascades [3], but in $\beta$-cells the action is predominantly pro-apoptotic. Various experiments have offered evidence supporting the apoptotic role of NF-kB. Inhibition of cytokine-induced NF-kB activation - either by a recombinant adenovirus $(\operatorname{AdIkB}(\mathrm{SA}))$ containing a nondegradable mutant form of $\mathrm{IkB} \alpha$ (S32A, S36A), or by stable transfection with a dominant negative inhibitor of NF-kB prevents cytokine-induced cell death in human islet cells and purified rat $\beta$-cells, respectively, as well as in mouse insulin producing MIN6 cells. In addition, intravenous administration of a NF-kB "decoy" inhibits alloxan-induced $\beta$ cell death and diabetes mellitus in mice. Mice deficient in NF-kB1 (p50) showed resistance to streptozotocin-induced diabetes. Furthermore, inhibition of the NF-kB pathway protects pancreatic $\beta$-cells from cytokine-induced apoptosis in vitro and in vivo from multiple low-dose streptozotocin (STZ)-induced diabetes. Inhibition of this process could potentially be an effective strategy for protecting $\beta$-cells. Thus, it seems that NF-kB activation has mostly proapoptotic effects in pancreatic $\beta$-cells. Ad- 
ditionally, hyperglycemia induces NF-kB activation in ex vivo isolated peripheral blood mononuclear cells (PBMCs) of patients with type 1 diabete.

Role of NF-kB in the pathogenesis of type 2 diabetes. Type 2 diabetes and insulin resistance are accompanied by varying degrees of hyperinsulinemia. Before the discovery of NF-kB, it was discovered that high doses of salicylates ameliorate hyperglycemia in type 2 diabetes NF-kB first became a chief suspect in the development of insulin resistance and type 2 diabetes after the milestone discovery that the anti-inflammatory agent, aspirin inhibits NF-kB and prevents degradation of the NF-kB inhibitor, IkB. Previous studies indicated that $\operatorname{IKK} \beta$ was key to the development of insulin resistance, while many others have highlighted the role of NF-kB in the pathogenesis of insulin resistance and type 2 diabetes. However, it was unknown whether IkB itself, or its downstream target, NF-kB, played the primary role in insulin resistance. Two independent studies one using the selective transgenic expression and the other using $\operatorname{IKK} \beta$ knockout in the liver - offer evidence to support the notion that NF-kB is, in fact, the major factor in insulin resistance. Overexpression of IKK $\beta$ in the liver, which causes sustained activation of NF-kB as seen in chronic liver inflammation, mimics high fat diet or obesity-induced insulin resistance. Conversely, attenuation of $\mathrm{NF}-\mathrm{kB}$ activation by co-expression of $\mathrm{IkB} \alpha$ in the liver not only diminishes the expression of NF-kB dependent genes, but reverses the phenotypes of type 2 diabetes as well. Systemic neutralization of IL-6 exhibited a significant improvement in insulin resistance in the mice with transgenic liver expression of IKK $\beta$. Similarly, administration of a specific inhibitor of IL-1 signaling ameliorated the inflammationinduced hyperglycemia. These results clearly suggest that NF-kB and its arget genes, such as $\mathrm{TNF} \alpha$, IL-1, and IL-6, are critical in the development of insulin resistance.

Therapeutic strategies for NF-kB inhibition and clinical application. Several agents already safely used in clinical practice have been recently shown to have properties which go beyond their traditional pharmacological action. These 'pleiotropic' properties include NF-kB inhibition, at least in the in vitro setting (Fig. 3). Many pharmaceutical companies have programmes to develop selective inhibitors of NF-kB, which include (1) directly targeting DNA binding activity of individual NF-kB proteins using small molecules or decoy oligonucleotides; (2) blocking the nuclear translocation of NF-kB dimers by inhibiting the nuclear import system; (3) stabilizing $\mathrm{IkB} \alpha$ protein by developing ubiquitination and proteasome inhibitors; (4) targeting signaling kinases such as IKK using small molecule inhibitors. All these therapeutic strategies are aimed at blocking NF-kB activity. With increasing knowledge of signaling pathways leading to NF-kB activation, multiple targets can be identified for potential interaction with small molecules. From the upstream kinases, such as IKK1, IKK2, MEKK-3, and NIK, to their downstream effector IkB E3 protein, 45 all represent attractive targets for novel drugs selectively regulating NF-kB function. Other components of the TNFa and IL-1 signaling pathways including TRADD, RIP, TRAF2, and TRAF6 and IRAK, as well as PKC isoforms and phosphoinositide 3-kinase, may provide additional targets for yet to be discovered inhibitors of NF-kB.

\section{Blockade of NF-kB to DNA binding.}

The most direct strategy for blocking NF- $\kappa \mathrm{B}$ activation is to block NF- $\kappa \mathrm{B}$ from binding to specific $\mathrm{kB}$ sites on DNA. Some sesquiterpene lactones (SLs) have been reported to inhibit NF- $\kappa \mathrm{B}$ [52] by interacting with Cys-38 in the DNA-binding loop of RelA [53]. Most SLs can also inhibit DNA binding through an analogous Cys residue in the DNA-binding loops of p50 and c-Rel. Some SLs, including parthenolide, have been shown to inhibit IKK $\beta$ through the reactive Cys-179 in the kinase activation loop [54]. Thus, SLs, which target both IKK activity and NF-kB subunit DNA binding, have multistep inhibitory activity within the NF-kB signaling pathway. Blocking specific NF-kB-DNA binding can also be accomplished with decoy oligodeoxynucleotides (ODNs). These ODNs have $\mathrm{kB}$ sites and competes for NF-kB dimer binding to specific genomic promoters [55]. These oligonucleotides have modifications to increase their stability and their affinity for NF-kB in vivo. Decoy 
ODNs have been reported to have therapeutic potential in a number of animal models of inflammation including rheumatoid arthritis and atherosclerosis.

Peptides with nuclear localization sequences inhibit NF-kB activity. Translocation of the NF-kB heterodimer from the cytoplasm to the nucleus is a central program in the regulation of the NF-kB pathway. Thus the development of inhibitors of NF-kB nuclear localization using recombinant peptides provides an approach that can mask the nuclear localization sequence (NLS) of NF-kB family members. This approach utilizes cellpenetrating peptides consisting of the NLS of the p50 NF-kB subunit, designated as SN50.

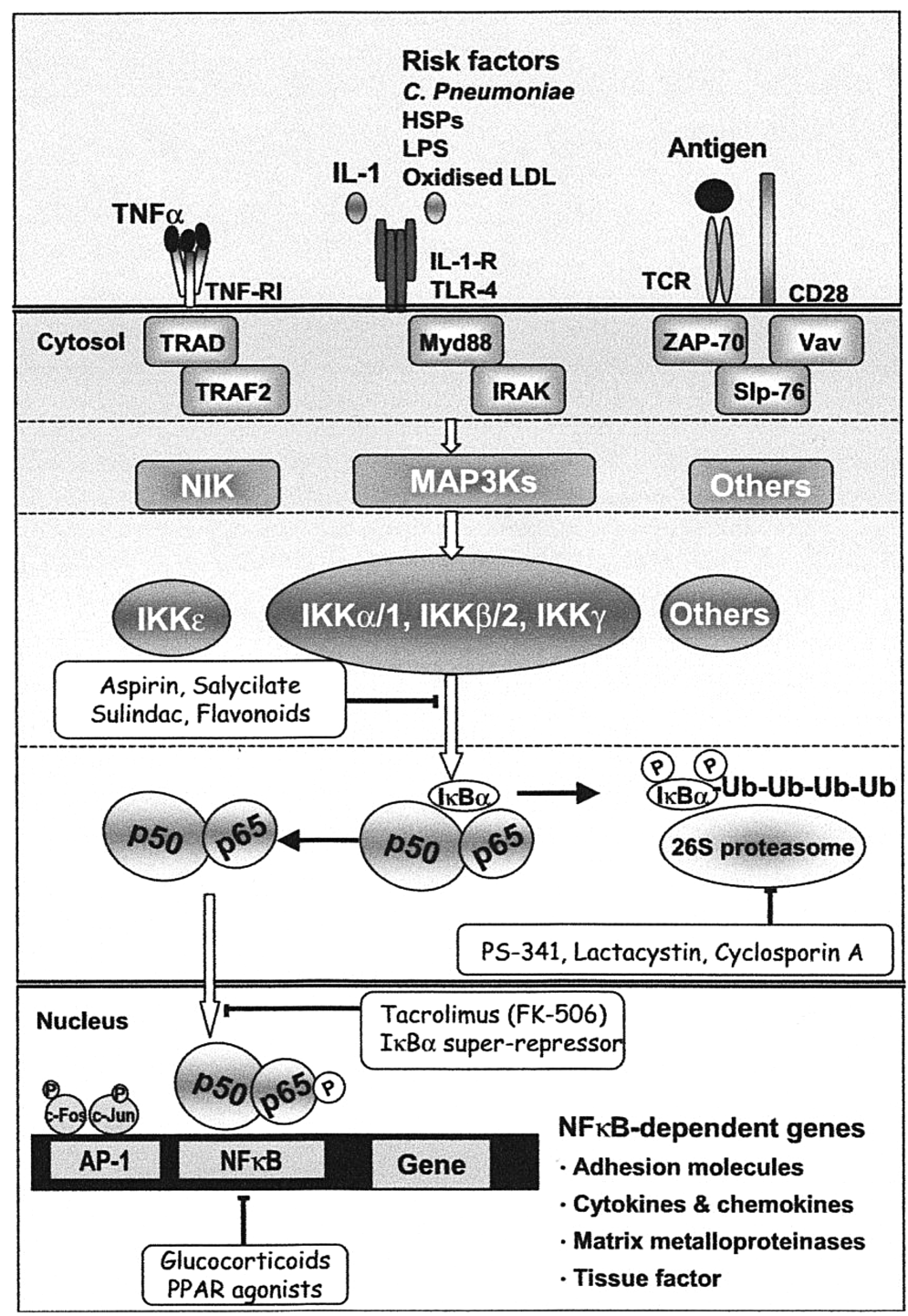

Fig. 3. NF-kB signaling in atherosclerotic lesions-effect of available NF-kB blocking agents. The NF-kB pathway is a convergence point for many pro-atherogenic stimuli. In the model illustrated, oxidized LDL, LPS and HSPs from infectious agents, as well as cytokines, and activated T cells, interact with different receptors at the cell surface. These, in turn, activate intracellular signaling proteins via a set of adaptor proteins and kinases such as NIK, initiating a cascade of phosphorylations. Central to the NF$\mathrm{kB}$ cascade is the large multi-subunit IKK complex, which is the point of convergence of multiple signals. Genes regulated by NF-kB include adhesion molecules, chemokine, MMP and cytokines, which play pivotal roles in atherosclerosis. The diagram also shows the NF-kB inhibitors currently available. Other agents which might inhibit $\mathrm{NF}-\mathrm{kB}$, such as statins, have not been included in this diagram as their mechanisms of action on the pathway have not been clarified. 
Introduction of SN50 into cell efficiently inhibits LPS - and TNF $\alpha$-induced NF-kB nuclear translocation and reduces NF-kB DNA binding in cultured endothelial and monocytic cells [56].

26S proteasome inhibitors prevent $I k B \alpha$ degradation and $N F-k B$ activation. The activation of IKK and the subsequent phosphorylation and degradation of $\operatorname{IkB} \alpha$ by the $26 \mathrm{~S}$ proteasome is a key step in the nuclear translocation of NF-kB and subsequent NF-kB-regulated transcription. Given the fundamental role of the proteasome [57] in the regulation of the NF-kB pathway, it provides a variety of natural and synthetic proteasome inhibitors has been studied, including epoxomicin, which the first proteasome inhibitor to enter human trials for rehumatoid arthritis and atherosclerosis [57]. The step before NF-kB leaves the cytoplasm involves the ubiquitination of $\mathrm{IkB}$ by the SCF- $\beta$-TrCP ubiquitin ligase complex followed by the rapid degradation of ubiquitinated IkB by the $26 \mathrm{~S}$ proteasome. Because $\mathrm{IkB} \alpha$ degradation is an important step in the NF-kB activation pathway, inhibiting the proteasomes that degrade $\mathrm{IkB} \alpha$ may also serve as a tool for pharmacological intervention. Very specific and potent proteasome inhibitors have been engineered by coupling boronic acid to dipeptides. The dipeptide boronate, bortezomib, the moststudied proteasome inhibitor in clinical development, has been shown to inhibit proliferation and induce apoptosis in head and neck. Bortezomib's antitumor properties correlate in part with its ability to inhibit $\mathrm{IkB} \alpha$ degradation. Other well-known proteasome inhibitors include lactacystine, N-cbz-Leu-Leuleucinal (MG132), MG115, and ubiquitin ligase inhibitors. In addition, recently identified a novel proteasome inhibitor, salinosporamide A (NPI-0052), which can suppress both constitutive and inducible NF-kB activation in a nanomolar range [58].

Inhibition of protein kinases. NF- $\mathrm{kB}$ activation requires the phosphorylation, polyubiquitination, and subsequent degradation of its inhibitory subunit, $\operatorname{IkB} \alpha$. Hence, inhibiting $\operatorname{IkB} \alpha$ phosphorylation ultimately inhibits NF-kB's transcriptional activity [59]. I $\kappa \mathrm{B} \alpha$ phosphorylation is carried out by IKK, a ser- ine/threonine protein kinase composed of three basic subunits: the kinases $\operatorname{IKK} \alpha, \operatorname{IKK} \beta$, and the regulatory subunit IKK $\gamma$ (NEMO). The IKK activation is usually the first common step in the integration of many NF-kB-activating pathways; therefore, one strategy for inhibiting NF-kB activation is to block IKK activation. However, although more than 150 agents have been shown to inhibit NF-kB activation at the IKK step, few studies have investigated the mechanism by which a given agent can inhibit IKK or its activation. The few IKK inhibitors for which a mechanism of action is known can be divided into three general groups: adenosine triphosphate (ATP) analogs, which show some specificity for interacting with IKK; compounds that have allosteric effects on IKK structure; and compounds that interact with a specific cysteine residue (Cys-179) in the activation loop of IKK $\beta$. ATP analogs include natural products such as $\beta$-carboline and synthetic compounds such as SC-839, which has an approximately 200 -fold preference for IKK $\beta$ compared to IKK $\alpha$ [60]. Compounds that have allosteric effects on IKK structure include BMS-345541, a synthetic compound that binds to an allosteric site on both IKK $\alpha$ and IKK $\beta$ and has an approximately 10-fold greater inhibitory effect on IKK $\beta$ than on IKK $\alpha$. Compounds that interact with Cys-179 IKK $\beta$ include thiolreactive compounds such as parthenolide, arsenite, and certain epoxyquinoids [61]; these compounds' interactions with Cys-179 are believed to interfere with phosphorylation-induced IKK $\beta$ activation because Cys- 179 is located between $\operatorname{Ser}^{177}$ and Ser ${ }^{181}$, which are required for $\operatorname{IKK} \beta$ activation in response to upstream signals such as tumor necrosis factor (TNF) and lipopolysaccharide (LPS). Genebased inhibitors can also block IKK activation. Specifically, mutations at the ATP-binding site or in the kinase activation loop can create dominant-negative $\operatorname{IKK} \alpha$ and $\operatorname{IKK} \beta$, which are capable of blocking NF-kB activation. Because of their distinct roles in the canonical and non-canonical NF-kB activation pathways, dominant-negative IKK 'mutants' can show stimulus-dependent inhibition. Adenoviral-mediated delivery of an IKK $\beta$ dominant-negative kinase has been shown to have 
therapeutic potential for airway inflammatory diseases such as asthma. NEMO can also serve as a target for inhibiting the IKK complex. In particular, introducing a cell-permeable 10 aminoacid peptide that corresponds to the NEMO-binding domain of IKK $\beta$ can block the binding of NEMO to IKK in response to TNF in the canonical pathway. While activation of NF-kB by many stimuli depends on the phosphorylation of IkBs at N-terminal sites by the IKK complex, the mechanism of NF-kB activation by ultraviolet (UV) radiation involves the IKK-independent phosphorylation of $\mathrm{IkB} \alpha$ at a cluster of C-terminal sites that are recognized by casein kinase II (CKII). CKII activity toward IkB $\alpha$ depends on p38 mitogen-activated protein kinase (MAPK) activation. CKII's role as a key survival signal that activates NF-kB and protects tumor cells from apoptosis suggests that CKII may be an attractive target for the treatment of diverse cancers. Apigenin, a plant flavonoid, and emodin, a plant anthraquinone, are competitive inhibitors of CKII that directly interact with the nucleotide-binding sites of CKII. Besides phosphorylating and subsequently degrading the molecules that inhibit NF-kB, protein kinases can also target the functional domains of NF-kB proteins themselves to optimally activate NF-kB. NF-kB proteins can be phosphorylated in the cytoplasm or nucleus by such kinases as glycogen synthase kinase $3 \beta$ (GSK3 $\beta$ ), TRAF-associated NF- $\kappa$ B activator (TANK)-binding kinase 1 (TBK1), PKAc, mitogen- and stress-activated protein kinase-1 (MSK-1), MAP3K NIK, Tpl2, PKC- $\theta$, PI3K, Akt, p38 MAPK, protein tyrosine kinase, PKC- $\delta$, RHO-kinase 2, mitogen activated protein kinase kinase 3 (MEKK3), and receptor tyrosine kinases such as epidermal growth factor receptor, human epidermal growth factor receptor 2 [62]. Antagonistic antibodies or kinase inhibitors that target these molecules may decrease NF-kB activation. Some kinase inhibitors that have the potential to inhibit NF-kB activation include SB203580 and PD0980589 (MAPK inhibitors); denbinobin (TAK1 inhibitor); tyrosine kinase inhibitors; rhein, (an MEKK inhibitor); TNAP; betaine (NIK inhibitors); epoxyquinol B (a TAK1 crosslinker); M2L (an extracellular signal-reg- ulated kinase 2 inhibitor); CCK-8 (a p38 kinase kinase inhibitor); KSR2 (an MEKK3 inhibitor); golli BG21 (a PKC inhibitor).

Other mechanisms of NF-kB inhibition. For example, statins, a group of drugs that act by inhibition of 3-hydroxy-3-methylglutaryl coenzyme A reductase, a rate-limiting enzyme in the cholesterol synthesis pathway, reduce the incidence of coronary events and stroke [63]. Surprisingly, statins reduce mortality with a very modest or null improvement in the percentage stenosis of lesions in humans, suggesting that properties other than lipid lowering may contribute to their benefit. In experimental atherosclerosis, statins reduce macrophage numbers, MMP and TF expression, cytokines and leukocyte adhesion molecules.

Furthermore, clinical trials have showed that statins may have a benefit even in patients with relatively low lipid levels but with high C-reactive protein levels. These effects might involve inhibition of $\mathrm{NF}-\mathrm{kB}$, as in vitro statins were shown to upregulate $\mathrm{IkBa}$ in smooth muscle cells and endothelial cells. A recent study also reported that cerivastatin can inhibit NF-kB activation and induction of MCP-1 and RANTES in smooth muscle cells infected with C. pneumoniae [64]. Recent work has also highlighted the role of peroxisome proliferator-activated receptors (PPAR), a subset of the nuclear hormone receptor superfamily. So far, three PPAR isoforms, a, h/y and g, have been identified. Fatty acids, leukotrienes and prostaglandins can act as natural ligand agonists for PPAR isoforms. Of interest to this review, agonist-activated PPAR $\alpha$ can antagonize the NF-kB pathway by interaction with relA, whereas PPARg-specific ligands inhibits expression of cytokines and adhesion molecules through repression of NF-kB. Agonist-induced PPARg can also influence DC maturation through NF-kB downregulation. Other drugs which may act through attenuation of the NF-kB pathway include anti-hypertensive angiotensin-converting enzyme inhibitors such as ramipril and quinapril. Administration of quinapril was found to reduce cytokine levels, macrophage infiltration and NF-kB activation in rabbit models of atherosclerosis [65]. Similarly, many of the effects of glucocorticoids, 
widely used in clinical therapy for their antiinflammatory and immunosuppressive properties, are thought to be mediated by interactions with the NF-kB pathway. One mechanism is induction of IkBa leading to cytosolic retention of NF-kB. However, other mechanisms are likely to be involved, such as repression of relA-dependent transactivation. The most common mechanism thought to account for the effects of non-steroidal anti-inflammatory drugs is COX-1 and -2 inhibition. However, additional mechanisms involving NF-kB have been suggested. Aspirin and sodium salycilates inhibit activation of NF-kB at concentrations found in the sera of patients treated with these agents for chronic inflammatory diseases, although their effect is unknown at lower concentrations, such as those used for platelet inhibition. The effect on NF-kB may be mediated by inhibition of IKK-2-dependent phosphorylation of IkB. Studies regarding the FANS in experimental studies on atherosclerosis have reached contrasting results. In a study in LDL-R knockout mice, low-dose aspirin induced a significant reduction of NF-kB activity in the aorta. In contrast, concentrations of indomethacin that inhibit COX activity do not prevent activation of the NF-kB pathway. Sulindac, a dual COX-1/COX-2 inhibitor, can also inhibit IKK-2 activity [66]. Finally, the immunosuppressive drugs cyclosporin $\mathrm{A}$ and tacrolimus (FK-506) inhibit the NF-kB pathway through at least two distinct mechanisms. Cyclosporin A inhibits proteasome activity, while tacrolimus blocks c-Rel nuclear translocation [67]. In the future, NF-kB signaling could be more selectively interfered at the levels of upstream receptors or adaptors, once signaling pathways specific for atherosclerosis have been identified, minimizing the possible harmful effects of complete NF-kB blockade. A potential mediator of vascular homeostasis is the triad cytokine system, which consist of receptor activator of nuclear factor-kB (RANK) ligand (RANKL), its receptor RANK, and the decoy receptor osteoprotegerin [68]. Unopposed RANKL activity in osteoprotegerin-deficient mice resulted inactivation of the NF-kB signaling pathway and low vascular calcification. Effects of RANKL inhibition by denosumab, a human monoclonal antibody against
RANKL, decreased activity NF-kB and reduced vascular calcium deposition $[69,70]$.

Atherosclerosis, and, in particular, its acute complications, and diabetes, are a major cause of mortality and morbidity around the world and is likely to continue to increase as a cause of death. Prevention and treatment of cardiovascular disease and diabetes are still a clinical challenge. Several lines of research have converged to suggest that the biology of the plaque is the real 'culprit' of clinical manifestations of atherosclerosis. Inflammatory signaling pathways are implicated in early atherogenesis, in the progression of lesions and finally in the acute complications of the disease. The increased understanding of the role of signaling pathways such as NF-kB will lead to the identification of therapeutic targets able to specifically downregulate pro-inflammatory responses in atherosclerotic plaques, increasing the therapeutic options of patients and doctors beyond control of risk factors and treatment of atherosclerosis. While blockade of NF-kB could be beneficial in atherosclerosis and diabetes there are obvious questions regarding the balance between efficacy and safety, as maintenance of appropriate levels of NF-kB activity is critical for immune and inflammatory responses and maintenance of homeostasis. Furthermore, recent studies in mice have suggested that chronic, complete blockade of NF-kB could even be harmful and interfere with resolution of inflammation and survival responses in atherosclerotic lesions. As a result, the best strategy to inhibit NF-kB activation in atherosclerosis remains to be ascertained. One concern about the use of some NF-kB inhibitors is the lack of specificity. For example, the proteasome, which is responsible for IkB degradation, has many other vital functions, and its inhibition causes several side effects. However, growing understanding about the heterogeneity of the proteasome could lead to development of inhibitors specific for the NF-kB pathway. Because available inhibitors lack the necessary specificity for tackling NF-kB activation avoiding major side effects, there is a need to identify appropriate therapeutic targets within the pathway in order to achieve specific inhibition. Moreover, it may not be feasible to block NF-kB 
for prolonged periods. The best timing for intervention, early vs. advanced stages and/or acute versus chronic phases of disease, needs to be considered, in an attempt to maximize benefits and minimize side effects. Transient NF-kB inhibition might be beneficial in acute coronary syndromes. Another possibility is local targeting of NF-kB during interventional procedures by drug-eluting stents using small molecules inhibitors, RNA interference or gene therapy. Finally, further understanding of the signaling events preceding NF-kB activation in atherosclerotic plaques will allow the targeting of specific receptors or adaptors within the NF-kB pathway. However, such approaches are still in the realm of the future, and the therapeutic potential of inhibition of the NF-kB pathway in atherosclerosis and diabetes are unknown, with further research needed to clarify clinical benefit. More questions than answers are arising from current research on the feasibility of NF-kB blockade in atherosclerosis and diabetes, and more research is warranted in this fast-moving field before definite conclusions can be reached. Nevertheless, the possibilities offered by a deeper understanding of regulation of inflammatory signaling, including not just NF-kB but also other pathways, open up the promise of specific inhibition of disregulated inflammatory mechanisms causing.

\section{ЛITЕРАТУРА (REFERENCES)}

1. Sarah JG, Johanson J. Atherosclerosis: molecular and cellular mechanisms, Weinheim, 2010: 398 p.

2. Sarah JG, Cressida L. Atherosclerosis: molecular and cellular mechanisms, Weinheim, 2010: 3-20.

3. Oeckinghaus A, Ghosh S. Cold Spring Harb Perspect Biol 2009; 1(4):a34.

4. Asano S, Fukuda Y, Beck F, et al. Science 2015; $347: 439-442$.

5. Li ZW, Karin M. NF-kB/Rel transcription factor family, N.Y. Springer Sci 2006:12-25.

6. Israel A. Cold Spring Harb Perspect Biol 2010; 2(3):a158.

7. Lee SH, Toth Z, Wong LY, et al. Clin Miciobiol Portal 2012; 3(6):e411-412.

8. Kray AE, Carter RS, Pennington KN, et al. J Biol Chem 2005; 280(43):35974-35982.

9. Hoesel B, Schmid JA. Mol Cancer 2013; 12:86-92.

10. Zamanian-Daryoush M, Mogensen TH, DiDonato JA, et al. Mol Cell Biol 2000; 20(4):1278-1290.

11. Adli M, Merkhofer E,Cogswell P. PLoS One 2010; 5(2):e9428.

12. Sun SC. Cell Res 2011; 21(1):71-85.

13. Andreakos E, Smith C, Kiriakidis S, et al. Arthritis Rheum 2003; 48(7):1901-1912.

14. Li Q,Verma IM. Nat Rev Immunol 2002; 2(10):725734 .

15. Solt LA, Madge LA, May MJ. J Biol Chem 2009; 284(40):27596-27608.

16. Roman-Blas JA, Jimenez SA. Osteoarthritis Cartilage 2006; 14(9):839-848.

17. Karin M. Ann Rheum Dis 2004; 63(2):i62-i64.
18. Kempe S, Kestler H, Lasar A, Wirth T. Nucleic Acids Res 2005; 33(16):5308-5319.

19. Ley K. Adhesion molecules: function and inhibition, Basel, 2007: 161 p.

20. Oeckinghaus A, Hayden MS, Ghosh S. Nature Immunol 2011; 12(8):695-708.

21. De Winther MPJ, Kanters E, Kraal G, Hofker MH. Atheroscler Thromb Vasc Biol 2005; 25:904-914.

22. Wilson SH, Best PJ, Edwards WD, et al. Atherosclerosis $2002 ; 160(1): 147-153$.

23. Bu DX, Johansson ME, Ren J, et al. Atheroscler Thromb Vasc Biol 2010; 30(12):2604-2610.

24. Gareus R, Kotsaki E, Xanthoulea S, et al. Cell Metab 2008; 8:372-383.

25. Kanters E, Pasparakis M, Gijbels MJ, et al. J Clin Invest 2003; 112(8):1176-1185.

26. Lion HC. NF-kB/Rel transcription factor family, N.Y. Springer Sci, 2006: 185 p.

27. Ferreira V, Van Dijk KW, Groen AK, et al. Atherosclerosis 2007; 192(2):283-290.

28. Sage AP, Tintut Y, Demer LL. Nat Rev Cardiol 2010; 7(9):528-536.

29. Breuss JM, Cejna M, Bergmeister H, et al. Circulation 2002; 105(5):633-638.

30. Gupta SC, Sundaram C, Reuter S, Aggrawal BB. Biochem Biophys Acta 2010; 1799(10-12):775-787.

31. Ji KT, Qian L, Nan JL, et al. Clinical Chem 2008; 54(1):24-38.

32. Cominacini L, Anselmi M, Garbin U, et al. J Am. Coll Cardiol 2005; 46(5):799-806.

33. Garelnabi M, Kakumanu S, Litvinov D. Oxidative stress and diseases, Croatia, 2012: 199-240. 
34. Chappel SJ, Cheng X, Mann GE. Redox Biol 2013; $1(1): 319-331$

35. Tehlivets O. J Lipids 2011; 2011:1-12.

36. Den Dekker MAM, Zwiers M, Van der Heuvel ER, et al. PloS One 2013; 8(12):e83084.

37. Satta N, Kruithof EKO, Fickentscher C, et al. Blood 2011; 117(20):5523-5531.

38. Park JE, Kim YI, Yi AK. J Immunol 2009; 182(10):6316-6327

39. Lawrence T. Cold Spring Harb Perspect Biol 2009; 1(6):a001651

40. Kim TW, Febbraio M, Robinet P, et al. J Immunol $2011 ; 186(5): 2871-2880$

41. Verstak B, Nagpai K, Bottomley SP, et al. J Biol Chem 2009; 284(36):24192-24203.

42. Xu S, Zhi H, Hou X, Jiang B. Biochem Biophys Res Commun 2011; 410(3):543-548.

43. Mallat Z, Taleb S, Ait-Oufella H, Tedyui A. J Lipid Res 2009; 50(Suppl):S364-S369.

44. Brasier A. Cardiovasc Res 2010; 86(2):211-218.

45. Matsushita N, Endo Y, Sato K, et al. PLoS One 2011; 6(8):e23324

46. Gilmore T, Mosialos G. Nuclear factor - kB: regulation and role in disease, Dortrecht, 2003: 89-114.

47. Niessner A, Weyand CM. Clin Immunol 2011; 134(1):25

48. Zernecke A. Atheroscler Thromb Vascul Biol 2015; 35(4):763-770

49. Moore KJ, Sheedy FJ, Fisher EA. Nat Rev Immunol 2013; 13(10):709-721

50. Saraiva M, O'Garra A. Nat Rev Immunol 2010; 10(3):170-181.

51. Chistiakov DA, Orekhov AN, Bobryshev YV. Acta Physiol 2015; 214(1):33-50.

52. Gilmore TD, Herscovitch M. Oncogene 2006; 25(51):6887-6899.
53. Tang JR, Michaelis KA, Nozik-Grayck E, et al. $J$ Immunol 2013; 190(6):4049.

54. Koprowska K, Czyz M. Postepy Hig Med Dosw 2010; 64(1):100-114

55. Tas SW, Vervoordeldonk MJBM, Tak PP. Curr Gene Ther 2009; 9(3):160-170.

56. Trask OJ. Nuclear factor kappa B (NF-kB) translocation, Bethesda, MD, 2012: 1-22.

57. Amschler K, Schön MP, Pletz N, et al. J Invest Dermatol 2010; 130(4):1073-1086.

58. Ahn KS, Sethi G, Chao TH, et al. Blood 2007; 110(7):2286-2295.

59. Zhang LL, Li Y, Wang Y, et al. PLoS ONE 2015; 42(2):339-345

60. Yoon JW, Kang JK, Lee KR, et al. J Toxicol Environ Health A 2005; 68(23-24):2005-2017.

61. Saadone A, Masters S, DiDonato J, et al. AJ Respir Cell Mol Biol 2007; 36(6):728-736.

62. Xu X, Steere RR, Fedorchuk CA, et al. PLoS ONE $2011 ; 6(11): \mathrm{e} 28216$.

63. Hölschermann H, Schuster D, Parviz B, et al. Atherosclerosis 2006; 185(2):240-245.

64. Chansrichavala P, Chantharaksri U, Sritara P, Chaiyaroj S. Asian Pacific J Allergy Immunol 2009; $27(1): 49-57$.

65. Marchesi C, Paradis P, Schiffrin EL. Trends Pharmacol Sci 2008; 29(7):367-374.

66. Mladenova D, Pangon L, Currey N, et al. Cell Commun Signal 2013; 11(1):73-84.

67. Du S, Hiramatsu N, Hayakawa H, et al. J Immunol 2009; 182(11):7201-7211

68. Sagalovsky S, Richter T. Int Med J 2012; 18(4):7178 .

69. Helas S, Goettsch C, Schoppet M, et al. Am J Pathol $2009 ; 175(2): 473-478$

70. Lerman DA, Mackenzie NCW, Zhu D, et al. Eur Heart J 2012; 33(1):1049-1049. 


\title{
РОЛЬ ПРОТЕЇНУ ЯДЕРНИЙ ЧИННИК КАППА В (NF-kB) У РОЗВИТКУ АТЕРОСКЛЕРОЗА ТА ДІАБЕТА: ПОТЕНЦІЙНА МІШЕНЬ ДЛЯ ТЕРАПІЇ
}

\author{
Долженко А. ${ }^{1}$, Ріхтер T. ${ }^{2}$, Сагаловські C. ${ }^{2}$ \\ ${ }^{1}$ Відділ біомедичних досліджень Інституту молекулярної медицини, Університет ім. Мартіна \\ Лютера, м. Галле-Віттенберг, Німеччина; \\ ${ }^{2}$ Відділ кардіологї, клініка Медіан, м. Бад Лаузік, Німеччина \\ s.sagalovsky@gmail.com
}

\begin{abstract}
Кардіоваскулярні захворювання та діабет займають провідне місце серед захворювань і показників смертності у всьому світі. Атеросклероз є основою розвитку багатьох серцевосудинних захворювань, характеризується накопиченням ліпідів та фіброзних елементів у артеріях, маючи схожість із таким хронічним запальним захворюванням як діабет. Загальні ріси, що об'єднують ці захворювання, включають екстравазацію лейкоцитів, утворення цитокінів, хемокінів і деградуючих матрікс ферментів. Ці захворювання мають загальні сигнальні шляхи, включаючи активацію сигнального каскаду ядерного чинника каппа В (NF-kB). У разі атеросклерозу i діабету серед традиційних чинників ризику, що сприяють активації сигнального шляху NF-kB, виділяють цитокіни, міжклітинні взаємодії та інфекційні агенти. Багато генів запалення беруть участь у розвитку патогенеза атеросклерозу й діабету через сигнальні протеїни NF-kB, активні форми яких присутні у цитоплазмі клітин. Таким чином, розуміння ролі сигнального каскаду NF-kB у розвитку атеросклерозу та діабету дозволяє виділити багато специфічних протеїнів як мішеней для пошуку речовин щодо лікування цих захворювань.
\end{abstract}

K л ю ч о в і с л о в а: атеросклероз, діабет, протеїн ядерний чинник NF-kB, запалення, терапевтичні мішені.

\section{РОЛЬ ПРОТЕИНА ЯДЕРНЫЙ ФАКТОР КАППА В (NF-kB) В РАЗВИТИИ АТЕРОСКЛЕРОЗА И ДИАБЕТА: ПОТЕНЦИАЛЬНАЯ МИШЕНЬ ДЛЯ ТЕРАПИИ}

\author{
Долженко A. ${ }^{1}$, Рихтер т. ${ }^{2}$, Сагаловски C. ${ }^{2}$ \\ ${ }^{1}$ Отдел биомедицинских исследований Института молекулярной медицинъ, Университет \\ им. Мартина Лютера, г. Галле-Виттенберг, Германия; \\ ${ }^{2}$ Отдел кардиологии, клиника Медиан, г. Бад Лаузик, Германия \\ s.sagalovsky@gmail.com
}

Кардиоваскулярные патологии занимают ведущее место среди заболеваний и показателей смертности во всем мире. Атеросклероз является основой развития многих сердечнососудистых заболеваний, характеризуется накоплением липидов и фиброзных элементов в артериях, имея сходство с таким хроническим воспалительным заболеванием, как диабет. Общие черты, объединяющие эти патологии, включают экстравазацию лейкоцитов, образование цитокинов, хемокинов и деградирующих матрикс ферментов. Развитие данных заболеваний имеет общие сигнальные пути, включая активацию сигнального каскада ядерного фактора каппа В (NF-kB). В случае развития атеросклероза и диабета, среди традиционных факторов риска, сопутствующих активации сигнального пути NF-kB, отмечают цитокины, межклеточные взаимодействия и инфекционные агенты. Многие гены воспаления участвуют в развитии патогенеза атеросклероза и диабета через сигнальные протеины NF-kB, активные формы которых присутствуют в цитоплазме клеток. Таким образом, понимание роли представленного сигнального каскада $\mathrm{NF}-\mathrm{kB}$ в развитии атеросклероза и диабета позволяет выделить многие специфические протеины как мишени для поиска лекарственных веществ лечения заболеваний.

K л ю ч е в ы е с л о в а: атеросклероз, диабет, ядерный фактор каппа В (NF-kB) протеин, воспаление, терапевтическая мишень. 


\title{
ROLE OF NUCLEAR FACTOR (NF)-kB PROTEIN IN ATHEROSCLEROSIS AND DIABETES: A POTENTIAL THERAPEUTIC TARGET
}

\author{
A. Dolzhenko ${ }^{1}$, T. Richter ${ }^{2}$, S. Sagalovsky ${ }^{2}$ \\ ${ }^{1}$ Biomedical Research Unit, Institute Molecular Medicine Martin-Luther University Halle-Wittenberg, \\ Germany; \\ ${ }^{2}$ Department of Cardiology Clinic Median, Bad Lausick, Germany \\ s.sagalovsky@gmail.com
}

Cardiovascular diseases and diabetes are the leading cause of morbidity and mortality in all countries. Atherosclerosis, the background for many cardiovascular diseases, is characterized by the accumulation of lipid and fibrotic entities in large arteries and bears many similarities with chronic inflammatory diseases such as diabetes. Common features include extravasation of blood-derived leukocytes, as well as production of cytokines, chemokines and matrix-degrading enzymes. There are also many shared signaling pathways, including activation of the nuclear factor $\mathrm{kB}(\mathrm{NF}-\mathrm{kB})$ cascade. In the pathology of atherosclerosis and diabetes NF-kB is essential to the cross-talk between cytokines, adhesion molecules and growth factors, leading to atherosclerotic plaque formation, growth and eventual rupture. The intent of this paper is to gather and summarize information on the role of NF-kB in the pathology of atherosclerosis and diabetes. Thus, it is essential to understand the role of this important signaling cascade in atherosclerosis and diabetes, in a quest for more specific therapeutic targets.

$\mathrm{K}$ e y w o r d s: atherosclerosis, diabetes, nuclear factor (NF)-kB protein, inflammation, therapeutic target. 